\title{
Hermenutika Tauhid; Kritik terhadap Penafsiran Amina Wadud tentang Nusyuz
}

\author{
Miftahul Janah \\ Institut Agama Islam Bakti NegaraTegal \\ Email: miftahuljinan@gmail.com \\ Muhammad Yasir \\ Universitas Islam Negeri Sultan Syarif Kasim Riau \\ Email: muhammad.yasir@uin-suska.ac.id
}

\begin{abstract}
This paper examines the paradigm, principles, methods, and results of Amina Wadud's interpretation, particularly regarding nusyuz. The interpretation paradigm refers to the hermeneutic of tauhid which understands that the Koran has a unified meaning from all parts of the verse. So that there is an integration between universal and particular things in the Qur'an. Geologically, Wadud's principle of interpretation refers to philosophical hermeneutics or the flow of objectives-cum-subjectivities, namely Gadamer. This group puts forward the "how to understand" area, not the area of how to understand the text correctly and objectively. There are three methods used by Wadud in interpreting the Qur'an; in what context a text is written or revealed, how is the grammatical composition of the text, finally how the whole text (verse), its Weltanschauung or way of life. While related to nusyuz, Wadud understands as a disruption of marital harmony. One of the criticisms of the interpretation of Wadud lies in his understanding that the utterance of qānitāt applies only to human obedience to Allah, not to the obedience of fellow living beings. But in Q.S. Al-Ahzab (33): 31 is not so.
\end{abstract}

Keywords: Hermeneutika Tauhid, Amina Wadud, Nusyus, Gender.

\begin{abstract}
Abstrak: Tulisan ini mengkaji paradigma, prinsip, metode dan hasil penafsiran Amina Wadud, khususnya tentang nusyuz. Paradigma penafsiran merujuk pada hermeneutika tauhid yang memahami bahwa Al-Qur'an mempunyai satu-kesatuan makna dari seluruh bagian-bagian ayatnya. Sehingga ada integrasi antara hal yang universal dan partikular dalam Al-Qur'an. Secara geneologi, prinsip penafsiran Wadud merujuk pada hermeneutika filosofis atau aliran obyektiviescum-subyektivies, yakni Gadamer. Kelompok ini lebih mengedepankan pada wilayah "bagaiman memahami", tidak pada wilayah bagaimana memahami teks dengan benar dan objektif. Terdapat tiga metode yang dilalui Wadud dalam menafsirkan Al-Qur'an; dalam konteks apa suatu teks ditulis atau diwahyukan, bagaimana komposisi tata bahasa teks tersebut, terakhir bagaimana keseluruhan teks (ayat), Weltanschauung-nya atau pandangan hidupnya. Sementara terkait nusyuz, Wadud memahami sebagai disruption of marital harmony. Salah satu kritik terhadap penafiran Wadud terletak pada pemahamannya bahwa lafad qānitāt hanya berlaku pada ketaatan manusia kepada Allah, tidak pada keta'atan sesama mahluk hidup, namun dalam Q.S. Al-Ahzab (33):31 tidak demikian.
\end{abstract}

Kata Kunci: Hermeneutika Tauhid, Amina Wadud, Nusyus, Gender. 
PENDAHULUAN

Satu kenyataan dan sebuah kepastian bahwa Al-Qur'an tidak akan termakan oleh zaman, di manapun dan kapanpun akan menjadi pedoman utama yang mesti dirujuk kembali untuk mencari solusi permasalahan umat. Salah satu problem atau permasalahan kontemporer adalah tentang status dan posisi wanita. Tentang hal tersebut, walau bukan hal yang baru, umum menjadi perdebatan di dalam kalangan Islam, yang selalu dikaji dalam berbagai sudut pandang, pendekatan atau metode yang AlQur'an menjadi rujukan utamanya. ${ }^{1}$ Pembacaan ulang terhadap teks AlQur'an dengan mempertimbangkan relasi antara lak-laki dan perempuan, dipicu oleh adanya gerakan feminisme yang ingin mensejajarkan posisi dan peran perempuan dan laki-laki atau kesadaran bahwa posisi perempuan telah tersubordinasikan. ${ }^{2}$

${ }^{1}$ Khoiruddin Nasution, Fazlur Rahman tentang Wanita (Yogyakarta: Tazzafa dan Accademika, 2002), 2.

2 Sukanti Suryocondro, "Timbulnya Perkembangan Gerakan Wanita Indonesia"
Pandangan feminisme muncul sebagai sebuah counter terhadap realitas sosial umat Islam yang terkadang tidak sejalan dengan spirit ajaran Islam itu sendiri, sebagaimana tertuang dalam Al-Qur'an. Islam sejak awal ditujukan sebagai agama pembebasan, begitu juga dengan pembebasan bagi kaum perempuan. Islam memerintahkan manusia untuk meperhatikan konsep keseimbangan dan keselarasan baik antar sesama umat manusia maupun dengan lingkungannya.

Amina Wadud merupakan seorang akademisi perempuan yang secara sadar ingin mengangkat ketimpangan sosial bagi wanita melalui pemahaman keagamaannya, khususnya dengan Al-Qur'an sebagai sumber keagamaan. Pemahaman keagamaan yang terjawentahkan dalam penafsiran dan sebagai bentuk resepsi hermenutis-intelektualis, tentunya mempunyai metode yang jelas dan ilmiah yang tentunya perlu diperbincangkan lebih jauh. Oleh

dalam Kajian Wanita dalam Pembangunan, (Jakarta: Yayasan Obor Indonesia, 1995), 30. 
karenanya, dalam tulisan ini mencoba menganalisis bagaimana kontruksi gagasan pemikiran Amina Wadud, terutama mengenai metode penafsiran yang bersandar pada istilah hermeneutika tauhid. Kedua, hasil dari metode tersebut tertuang dalam pemahamannya tentang nusyuz sebagai disruption of marital harmony. Tentu dalam pemahamannya tersebut, perlu adanya kritik yang merupakan points utama dalam tulisan ini.

\section{PEMBAHASAN}

\section{A. Sekilas tentang Amina Wadud}

Nama lengkapnya adalah Amina Wadud Muhsin, ia lahir di Amerika pada 25 September 1952 di Bethesda, Maryland. ${ }^{3}$ Ia berasal dari keturunan blasteran antara Afrika dan Amerika, ibunya berasal dari Afrika dan bapaknya seorang Amerika yang merupakan seorang pendeta. Wadud memeluk Islam pada tahun 1972. Wadud merupakan janda dengan lima anak, dua laki-laki

3 Asma Barlas. Suha Taji-Farouki, ed. Modern Muslim Intellectuals and the Qur'an. (London: Oxford Univercity Press, 2005), 98. dan tiga perempuan. Anak lakilakinya bernama Muhammad dan Khalilullah, sedangkan yang perempuan adalah Hasna, Sahar, dan Ala. ${ }^{4}$

Studinya di perguruan tinggi di mulai di University Of Pennsylvania bidang pendidikan (Education). Ia meraih gelar sarjana (BS) pada tahun 1975, kemudian ia melanjutkan studi pasca sarjana ke The University of Michigan, Gelar Master (MA) diraihnya pada bulan Desember 1982 di bidang kajian-kajian ketimuran dekat (Near Castera Studies). Dari Universitas yang sama ia akhirnya menyambet gelar (Ph.D) pada Agustus 1988 dibidang kajian-kajian keIslaman dan Bahasa Arab (Islamic Studies and Arabic).

Wadud pernah menjadi dosen di jurusan bahasa Inggris pada College of Education Universitas Qar Yunis, Libya. Setelah itu, Wadud mengajar di Islamic Community Center School di Philadelphia. Pada

4 Amina Wadud, Qur'an and Woman: Rereading the Sacred Text from a Woman's Perspective (London: Oxford University Press, 1999), xxiv. 
tahun 1982 ia menjadi instruktur bahasa Inggris di Institute for English Language Instruction Kairo, Mesir pada Program Adult Education Program Transciber. Selama di Kairo, ia berkesempatan mendalami Bahasa Arab lanjut secara intensif di Amerika University, juga mendalami Studi Islam di Universitas Kairo dan Universitas Al-Azhar. Sepulang dari Mesir ia menjadi Asisten Peneliti di The University of Michigan pada bagian pengembangan bahan-bahan pengajaran bahasa Arab, 1984-1986. ${ }^{5}$

Beberapa karya Wadud dalam bentuk yakni; Qur'an and Woman: Rereading the Sacred Text from a Woman's Perspective. Inside the Gender Jihad: Women's Reform in Islam. Sedangkan dalam bentuk artikel, "Muslim Women as Minority", "The Dynamics of Male-Female Relations In Islam", "Understanding the Implicit Qur'anic Parameters to the Role Women in the Modern Context".

\section{B. Paradigma}

Penafsiran:

\section{Hermenutika Tauhid}

${ }^{5}$ Ahmad Baidawi, Tafsìr Feminis; Kajian Perempuan dalam alQur'ān dan Para Mufassir Kontemporer, (Bandung: Nuansa, 2005), 109.
Kegelisahan Wadud berangkat dari kenyataan bahwa perempuan dalam kehidupan bermasyarakat umumnya termarjinalkan. Interpretasi tentang perempuan dalam Al-Qur'an yang ditafsirkan oleh para mufassir laki-laki beserta pengalaman dan latar belakang sosial mereka yang dinilai telah menyudutkan perempuan dalam perannya ditengah publik dan dirasa tidak ada keadilan. Pada sisi lain, pemikiran Wadud muncul dalam konteks historis yang erat kaitannya dengan pengalaman dan pergumulan para perempuan Afrika-Amerika dalam memperjuangkan keadilan gender. Karena selama ini, dalam kehidupan bermasyarakat maupun berkeluarga, relasi antara laki-laki dan perempuan menunjukan adanya bias patriarki. Konsekuensinya kurangnya keadilan yang proporsional yang didapatkan oleh para perempuan. ${ }^{6}$

Kembali pada akar masalah dalam hal ini, yakni awal mula

6 Charles Kurzman, Liberal Islam: A Source Book (London: Oxford Uiversity Press, 1998), 127. 
penciptaan manusia yang biasanya menjadi dasar adanya perbedaan antara laki-laki dan perempuan. Dalil penciptaan manusia dengan merujuk pada Q.S al-Nisa (04): 1, menurutnya, kata "nafs" secara umum diterjemahkan sebagai diri dan jamaknya adalah anfus sebagai diridiri. Namun Al-Qur'an tidak pernah menggunakannya untuk menunjuk pada sesuatu diri yang diciptakan selain manusia. Adapun secara teknis dalam Al-Qur'an, nafs merujuk pada asal-muasal, "nafs" tidak maskulin maupun feminim, dan menjadi esensial dari setiap orang, laki-laki dan perempuan, begitu pula tidak disebutkan secara eksplisit bahwa perempuan diciptakan dari nafs Adam saja. Karena itu, pada dasarnya di hadapan Tuhan, status dan posisi laki-laki dan perempuan adalah sama dan sederajat. ${ }^{7}$

Al-Qur'an pada dasarnya berusaha menimalisir perbedaan antara laki-laki dan perempuan, atau menghilangkan pentingnya

7 Amina Wadud, Qur'an and Woman..., 19. perbedaan jenis kelamin tersebut. Akan tetapi posisi, struktur atau definisi tentang peran bagi setiap jenis kelamin tidak dikemukakan dalam Al-Qur'an. ${ }^{8}$ Bila laki-laki dan perempuan berasal dari penciptaan yang sama, lantas mengapa dalam wilayah penafsiran atau realitas yang ada sangat jauh berbeda? Hal ini dimungkinkan adanya budaya patriarki dan bias gender dalam penafsiran Al-Qur'an yang kebanyakan didominasi kaum lakilaki. Wadud percaya bahwa yang menjadikan perempuan sebagai second personality bukanlah agama, melainkan sebuah penafsiran yang mempunyai sosio historis yang berbeda-beda. ${ }^{9}$ Dengan demikian, secara tidak langsung Wadud menegaskan ada nilai-nilai yang bersifat absolut dalma agama, yang tidak dapat diganggu gugat, dan ada pula nilai-nilai yang bersifat relatif. Nilai-nilai absolut merujuk pada Al-

${ }^{8}$ Amina Wadud, Inside the Gender Jihad: Women's Reform in Islam (Oxford: Oneworld, 2006), 9.

${ }^{9}$ Amina Wadud, Qur'an and Woman..., xi 
Qur'an mempunyai kebenaran absolut dan abadi. Kendati demikian, latar belakang kehidupan seorang penafsir (mufassir) akan tetap mempengaruhi hasil dari pembacaan dan pemahaman terhadap teks. Maka maka hasil penafsiran dari Al-Qur'an tersebut tidak memiliki kebenaran absolut, namun hanya relatif. Dengan kenyataan tersebut, Wadud menggagas sebuah alternatif penafsiran yang diyakininya lebih memperlihatkan kesetaraan gender. Ia menyebutnya dengan tafsir "hermeneutika tauhid". Hermeneutika tauhid menekankan bahwa Al-Qur'an mempunyai satu-kesatuan makna dari seluruh bagian-bagian ayatnya. Salah satu tujuan hermeneutika tauhid adalah menjelaskan dinamika antara hal-hal yang universal dan partikular dalam Al-Qur'an. ${ }^{10}$

Hermeneutika tauhid yang diusung oleh Wadud, walau dengan istilah yang baru, namun secara prinsip dan intinya telah diwacanakan oleh beberapa ulama

10 Amina Wadud, Qur'an and Woman..., xii. sebelumnya. Konsep niz\}am AlQur'an yang dicetuskan oleh alFarahi mislanya, walau berangkat dari paham surah as a unity (kesataun surat yang memilki tema sentral), namun berakhir pada pemahaman bahwa Al-Qur'an merupakan satu kesatuan yang tersusun rapi yang satu ayat dengan ayat lain atau surat dengan surat lain terintegrasi dan berhubungan. ${ }^{11}$ Selain itu, pandangan bahwa Al-Qur'an sebagai satu kesatuan juga dapat ditemukan dalam pemikiran Fazlur Rahman. Berangkat dari kritiknya terhadap mufassir klasik yang cenderung memperlakukan Al-Qur'an secara atomistik (ayat per ayat), maka perlu adanya metodologi penafsiran yang komprehensif dan holistik, sehingga dapat menghasilkan suatu weltanschaung (pandangan-dunia) AlQur'an yang kohesif dan utuh. ${ }^{12}$ Kenyataan ini, pada akhirnya mengembangkan metode penafsiran

11 Miftahul Jannah, 'Niẓām Al-Qur'ān', MAGHZA: Jurnal Ilmu Al-Qur'an Dan Tafsir, 3.1

(2018),

79-92 https:/ / doi.org/10.24090/maghza.v3i1.1957.

12 Fazlur Rahman, Islam and Modernity (Chicago: University Press, 1982), 2-3. 
maudhui atau tematik dalam memahami ayat-ayat Al-Qur'an dengan kasus atau tema tertentu.

Paradigma penafsiran Wadud yang berawal dari konsep penciptaan, dapat dilihat dari dua sudut pandang, yakni sebagi tafsir dalam arti produk atau hasil dan tafsir dalam arti proses. ${ }^{13}$ Sudut pandang pertama, ingin mengutarakan bahwa laki-laki dan perempuan hendaknya dilihat sebagai paham tauhid (bersatu), saling melengkapi dan saling mengisi satu dengan yang lainnya. Dengan kata lain, tidak ada fungsi eksklusif bagi kedua jenis kelamin yang digambarkan oleh Al-Qur'an. Sehingga, baik laki-laki dan perempuan memiliki potensi sama untuk berpartisipasi secara konkret dalam menjalankan fungsi-fungsinya. Sudut pandang ini, umum diwacanakan oleh para tokoh feminisme, seperti Fetimma Mernissi, Riffat Hassan atau Asghar Ali Engineer. Dalam sekup ini, ingin

13 Abdul Mustaqim, Pergeseran Epistemologi Tafsir (Yogyakarta: Putaka Pelajar, 2008), 33. mendobrak bagaimana sebuah produk penafsiran itu bebas dari bias gender dan tidak ketidak adilan.

Sudut pandang kedua, dengan bersandar bahwa tidak ada perbedaan antar laki-laki dan perempuan, dalam sekup tafsir dalam arti proses, maka bisa dipahami bahwa baik laki-laki dan perempuan berhak untuk menafsiri Al-Qur'an. Tafsir tidak hanya milik laki-laki, namun perempaun boleh menasirkan Al-Qur'an. Hal ini secara prinsip tidak jauh perbeda dengan konsep yang ditawarkan Khaled Abu Fadl dengan terma otoritarianisme penafsiran. Otoritas manusia dalam menafsirkan Al-Qur'an merupakan pemberian Allah. Akan tetapi dalm prosesnya, sebuah penafsiran bersifat otoritarianisme yakni sebuah tindakan mengunci atau mengurung kehendak Allah dalam sebuah penetapan dan penetapan tersebut sebagai sesuatu yang pasti dan absolut. ${ }^{14}$ Setiap manusia memiliki otoritas untuk menafsirkan Al-

14 Khaled Abou el-Fadl, Speking in God's Name Islamic Law, Authority and Women (England: Oneworld Oxfor, 2003), 93 
Qur'an, baik itu laki-laki atau perempuan yang merupakan pemberian Allah. Namun yang tidak diperbolehkan adalah bagiamana penafsiran tersebut bersifat otoritarianisme yang mengalahkan dan menyalahkan penafsiran lainnya.

\section{Prinsip Penafsiran}

Sebagaimana telah diutarakan sebelumnya, ada nilai yang obsolut dan relatif dalam sebuah agama. Bila pemahaman manusia terhadap teks Al-Qur'an memuat kebenaran yang relatif, tentunya dalam penafsiran tersebut pantas untuk dikatakan tidak benar-benar objektif. Dalam hal ini Wadud mengatakan "No method of Qur'anic exegesis is fully objective" ${ }^{15}$ Selama ini tidak ada suatu metode penafsiran yang benar-benar objektif, karena seorang penafsir seringkali terjebak perjudice-prejudicenya, sehingga kandungan teks itu menjadi tereduksi dan terdistorsi maknanya. Selain memahami bahwa tidak ada penafsiran yang benar-benar objektif, Setiap pemahaman dan penafsiran

15 Amina Wadud, Qur'an and Woman..., 1 . terhadap suatu teks termasuk teks kitab suci Al-Qur'an tidak terlepas dari perspektif mufassirnya. Cultural background, prejudice yang melatarbelakanginya yang oleh Amina Wadud disebut prior texs, sehingga tidak mengherankan meskipun teks itu tunggal, jika dibaca oleh beberapa orang hasilnya akan bervariasi, terkait dengan ini Wadud dengan tegas mengatakan, "Although ear reading is unique, the understansing of various readers of single text will converge of many points". ${ }^{16}$

Prinsip penafsiran Wadud, secara geneologi dapat dikembalikan pada tokoh hermeneutika filosofis atau aliran obyektivies-cumsubyektivies, yakni Gadamer. ${ }^{17}$

16 Amina Wadud, Qur'an and Woman..., 1 .

17 Hermeneutika digolongkan menjadi tiga kelompok pemikiran, yakni hermeneutika teoritis (epistimologi), hermeneutika filsafat (ontotlogi) dan hermeneutika kritis. Dalam tipologi yang digunakan Sahiron adalah aliran obyektivis, aliran obyektivies-cum-subyektivies dan aliran subyektivis. Lihat Josep Bleicher, Contemporery Hermeneutis: Hermeneutis as Method, Philosofhy and Critique (London: Raoutlege \& Kegan Paul, 1980), hlm. 15. Sahiron Samsuddin, Hermeneutika dan 
Hermeneutika filosofis, menitik beratkan pada "bagaiman memahami", bukan pada wilayah bagaimana memahami teks dengan benar dan objektif. Beberapa teori hermeneutik Gadamer yang berkaitan dengan pemahaman Wadud dalam metode penafsiran, bahwa mufassir memiliki parpemahaman sebelum menafsirkan. Sehingga terjadi dialek antara dua horizon yaitu horizon penulis atau pengarang dan penafsir atau pembaca, masa lalu dan masa kini.18 Selain itu, setiap mufassir harus harus mengakui adanya keterpengaruhan dalam dirinya, konsep ini menguatkan konsep sebelumnya. Sehingga semua produk penafsiran tidak bisa sampai pada kata obyketif, karena ada terpengaruhi oleh konteks atau latar belakang mufassir itu sendiri, sebagimana ynag dikatakan Wadud sebelumnya.

Pengembangan Ulum Al-Qur'an (Yogyakarta: Nawesea Press, 2009), 27.

18 Hans Georg Gadamer, Truth and Method (New York: Seabury Press, 2004), 274.
Lebih jauh Wadud mencoba mengklasifikasi bentuk sebuah penafsiran Al-Qur'an. Ia menagtakan "I put interpretations of woman in theQur'an into three categories:" yakni: tafisir tradisional, reaktif dan holistik. ${ }^{19}$ Kategori pertama merujuk pada upaya pemahaman terhadap teks Al-Qur'an disesuaikan dengan pokok bahasan spesifik sesuai dengan keinginan atau keahlian mufassirnya, seperti hukum (fiqh), nahwu, sharaf, sejarah, tasawuf dan lain sebagainya. Model tafsir semacam ini lebih bersifat atomistik. Artinya penafsiran terhadap teks AlQur'an dilakukan secara ayat perayat dan tidak tematik, sehingga pembahasan dan pemaparannya cenderung parsial. Tentunya tidak ada upaya untuk mengkorelasikan dan mengkaitkan tema-tema tertentu menurut Al-Qur'an itu sendiri. Lebih lanjut, tafsir model tradisional ini terkesan eksklusif, ditulis hanya oleh kaum laki-laki. Tidaklah mengherankan kalau hanya

19 Amina Wadud, Qur'an and Woman..., 2. 
kesadaran dan pengalaman kaum pria yang diakomodasikan di dalamnya.

Tafsir reaktif, yaitu tafsir yang berisi reaksi para pemikir modern terhadap sejumlah hambatan besar yang dialami perempuan yang dianggap berasal dari Al-Qur'an. Persoalan yang sering dibahas dan metode yang digunakan pada kategori yang kedua ini sering kali berasal dari gagasan kaum feminis dan rasionalis, tapi tanpa dibarengi analisis yang komprehensif terhadap ayat-ayat yang bersangkutan. Dengan demikian, meskipun semangat yang dibawanya adalah pembebasan (liberation), namun tidak terlihat hubungannya dengan sumber idiologi dan teologi Islam, yakni AlQur'an.

Ketiga tafsir holistik, tafsir yang menggunakan metode komprehensif dan merelevansikan dengan berbagai persoalan, baik sosial, moral ekonomi, politik, termasuk isuisu perempuan yang muncul di era modernitas. Dari tiga tipologi tersebut, Wadud dapat diposisikan pada tipologi yang ketiga, yakni sebagai upaya menafsirkan ayat-ayat Al-Qur'an secara komprehensif dan melihat konteks kekinian tanpa adanya bias gender dalam penafsiran tersebut.

Tipologi yang disebutkan Wadud, tidak jauh berbeda dengan tipologi Abdul Mustaqim atau Sahiron Samsuddin yang membagai penafsiran menjadi tiga kategori. Pemikir pertama membagi penafsiran menjadi; tafsir era formatif dengan nalar mitis, tafsir afirmatif dengan nalar ideologis, dan tafsir reformatif dengan nalar kritis. ${ }^{20}$ Sedangkan Sahiron menggunakan terma quasiobyektivis tradisionalis, quasi-obyektivis modernis dan subyektivis. ${ }^{21}$ Namun yang perlu ditekankan bahwa pembagian yang dilakukan Wadud berdasarkan pemahaman mufassir terhadap ayat-ayat perempuan dalam Al-Qur'an, bukan berdasarkan waktu atau metodis. Oleh karenanya istilah "tradisionalis" terasa kurang serasi

20 Abdul Mustaqim. Pergeseran Epistemologi Tafsir, 34-58.

21 Sahiron Syamsuddin, Hermeneutika dan Pengembangan Ulum al-Qur'an..., 73-76. 
bila disandingkan dengan istilah reaktif atau holistik. Walaupun istilah tersebut dapat dipahami secara seksama bila melihat penjelasan lebih lanjut.

Pada dasarnya yang diinginkan Amina Wadud adalah bagaimana menangkap spirit Al-Qur'an secara utuh, holistik dan integral. Sehingga, dalam penafsiran tidak terjebak pada teks-teks yang bersifat parsial dan legal formal. Akan tetapi lebih menekankan bagaimana proses menangkap keseluruhan ide dan spirit (ruh) yang ada di balik teks tersebut. Karena problem utama dalam penafsiran Al-Qur'an sesungguhnya terletak pada bagaimana memahami teks AlQur'an (nass) yang terbatas dengan konteks yang tak terbatas. Pada sisi lain, dalam waktu yang bersamaan terdapat hasrat untuk menjadikan AlQur'an selalu relevan dengan perkembangan dan tuntutan zaman. Dengan demikian, mufassir harus dapat menangkap prinsip-prinsip fundamental yang tak dapat berubah dalam teks Al-Qur'an itu sendiri, lalu penafsir melakukan refleksi yang unik untuk melakukan kreasi penafsiran sesuai dengan setting sosiokultural masyarakat zamannya.

$$
\text { Penafsiran Wadud }
$$
dikategorikan dalam tafsir holistik, namun dalam wilayah pemikiran Islam, Wadud dapat diposisikan sebagai pemikir yang the progressive ijtihadists, suatu istilah yang digunakan Abdullah Saeed.22 The progressive ijtihadists merupakan golongan yang berusaha menafsiri ulang pemahaman agama (AlQur'an) agar dapat disesuaikan dan relevan untuk masa sekarang. Beberapa ciri yang menunjukan bahwa Wadud dalam kategori ini adalah pandangan bahwa perlunya metodelogi baru dalam menafsirkan Al-Qur'an agar dapat memcahkan masalah kontemporer. Selain itu, pemikiran Wadud menitik beratkan

22 Setidaknya ada enam kategori yang Abdullah Saeed dalam menggambarkan pemikiran Islam modern, selian the progressive ijtihadists, yakni the legalisttraditionalist, the theological puritans, the political islamist, the islamist extremists, dan the secular muslims. Lihat Abdullah Saeed, Islamic Thought: An Introduction (London and New York : Routledge, 2006), 142. 
pada keadilan sosial, keadilan gender atau HAM.23

\section{Metode Penafsiran}

Metode penafsiran Wadud pada dasarnya didasarkan pada kerangka penafsiran Fazlur Rahman. Rahman berpendapat bahwa metode dan penafsiran yang diwarisikan oleh khazanah keilmuan Islam klasik dianggap telah gagal memaparkan pesan-pesan Al-Qur'an secara padu dan koheren. Hal ini diakibatkan oleh kaidah penafsiran ayat perayat, serta kecenderungan terhadap penggunaan ayat-ayat Al-Qur'an secara atomistik. Kalangan mufassir dan umat Islam pada umumnya tidak dapat menangkap keterpaduan pesan Al-Qur'an yang dilandaskan atas suatu weltanschauung atau worldview (pandangan dunia) yang pasti. ${ }^{24}$ Kenyataan itu pula yang mengilhami ketertarikan Wadud untuk menggunakan metode yang ditawarkan Rahman. Dengan jelas ia mengatakan "thus, I attempt to use the

\footnotetext{
${ }^{23}$ Abdullah Saeed, Islamic Thought, 150.

24 Fazlur Rahman, Islam and Modernity,
} 2-3. method of Qur'anic interpretation proposed by Fazlur Rahman". ${ }^{25}$

Dalam konteks ini, menggunakan metode hermeneutika Al-Qur'an sebagaimana ditawarkan Fazlur Rahman, bertujuan untuk menafsirkan ulang makna AlQur'an. ${ }^{26}$ Metode penafsiran Fazlur Rahman dikenal luas dengan nama "double movement", yakni sebuah gerakan ganda dalam sebuah alur penafsiran. ${ }^{27}$ Berangkat dari konteks sekarang ke masa Al-Qur'an diturunkan dan kembali lagi ke masa kini. Dengan alur penafsir ini, selain kembali melihat konteks historis sebuah ayat diturunkan, juga dapat mengambil legal spesifik dan ideal moral sebuah ayat Al-Qur'an. Kemudian, melihat situasi masa kini dengan cermat dan menerapkan apa yang dihasilkan dalam gerakan pertama kedalam situasi masa kini. ${ }^{28}$ Metode ini yang akan menghasilkan

25 Amina Wadud, Qur'an and
Woman..., 3 .

26 Amina Wadud, Inside the Gender Jihad..., 14 .

27 Fazlur Rahman, Islam and Modernity..., 6.

28 Fazlur Rahman, Islam and Modernity..., 7-8. 
penafsiran dan pemaknaan baru menurut pandangan Wadud. Karena ayat-ayat Al-Qur'an yang diturunkan dalam kurun waktu tertentu dalam sejarah mempunyai keadaan umum dan khusus yang melingkupinya, selain ia juga menggunakan ungkapan yang relatif mengenai situasi tertentu. Karenanya pesan AlQur'an tidak bisa direduksi oleh situasi historis pada saat ia diwahyukan saja.

Wadud menawarkan metode hermeneutik untuk menafsirkan AlQur'an, yang dalam pengoperasiannya untuk memperoleh kesimpulan makna suatu teks (ayat), selalu berhubungan dengan tiga aspek dari sebuah teks. Pertama, dalam konteks apa suatu teks ditulis atau dalam konteks apa ayat itu diwahyukan. Dalam kaitan ini Wadud menelusuri data-data sejarah, khususnya yang berkaitan dengan peristiwa turunnya ayat dan periode umum turunnya ayat tersebut untuk melakukan analisis. Tindakan ini sama halnya dengan melihat asbab nuzul atau sy'an al-nuzul atau diistilahkan oleh Rahman dengan sebab makro dan sebab mikro. ${ }^{29}$ Dengan mengembalikan pemahaman sebuah teks pada konteks yang melingkupinya, secara tidak langsung menegaskan bahwa Wadud adalah Gadamerian.

Kedua, bagaimana komposisi tata bahasa teks (ayat) tersebut (bagaimana pengungkapannya, apa yang dikatakannya). Dalam hal ini Wadud secara seksama mengurai penggunaan bentuk bahasa yang digunakan dalam Al-Qur'an baik itu dalam bentuk mudzakar dan

${ }^{29}$ Istilah sy'an al-nuzul digunakan oleh al-Farahi dan dibedakan dengan asbab nuzul, istilah pertama sepadan dengan asabab nuzul makro yang diperkenalkan oleh asy-Syatibi, yang didefinisikan sebagai situasi dan kondisi yang melingkupi orang yang mengajak bicara, orang yang diajak bicara dan pembicaraanya. Tahap selanjutnya dielaborasi secara detil oleh Fazlur Rahman. Asbāb al-nuzūl makro adalah latar belakang sosio-historis masyarakat Arab secara keseluruhan, yaitu memahami situasi makro dalam kondisi Arab pra Islam dan ketika Islam datang. Sedangkan dalam pandangan al-Farahi sy'an al-nuzul adalah bagiamana keadaan manusia atau masyarakat dan perilakunya. Hamim Ilyas, Asbab al-nuzul Dalam Studi Al-Qurán, dalam Yudian W. Asmin (ed.), Kajian Tentang Al-Qurán dan Hadis: Mengantar Purna Tugas Prof. Drs. H.M. Husein Yusuf (Yogyakarta: Forum Studi Hukum, 1994), 73. 
muanastnya. Hal ini sangat penting karena dalam kenyataannya, AlQur'an menggunakan bentuk yang beragam, adakalanya ekslusif untuk laki-laki dan wanita, adakalanya bentuk kedua-duanya. Persoalannya penggunaan bentuk yang ekslusif belum tentu tujuannya adalah untuk pihak tertentu. Karena memang bahasa Arab tidak mengenal bentuk netral. Sehingga pandangan baru mengenai bahasa Al-Qur'an memang sangat diperlukan.

Ketiga, bagaimana keseluruhan teks (ayat), Weltanschauung-nya atau pandangan hidupnya. ${ }^{30}$ Dapat diartikan penafsiran tidak dapat dipisahkan dari konteks dan pengalaman sosial, maka Al-Qur'an harus dipahami sesuai dengan konteksnya. Sehingga makna teks menjadi "hidup" tidak beku, dan kaya akan makna. Teks akan menjadi dinamis pemaknaannya dan selalu kontekstual, seiring dengan perkembangan budaya dan peradaban manusia.

30 Amina Wadud, Qur'an and Woman..., 3.
Menafsirkan ayat-ayat AlQur'an yang berkaitan dengan perempuan, baik itu terspisah atau bersamaan dengan terma yang merujuk laki-laki, akan dikaji dengan metode tafsir Al-Qur'an bi Al-Qur'an. Namun secara spesifik, langkah penafsiran tafsir Al-Qur'an bi AlQur'an dikembangkan, sehingga setiap ayat yang hendak ditafsirkan dianalisis dalam beberapa level, ${ }^{31}$ pertama, dalam konteksnya, yakni dalam konteks apa sebuah ayat tersebut ada atau dengan kata lain ayat tersebut membicarakan apa. Dalam level ini, bisa disamakan bahwa setiap ayat mencerminkan tema atau pembahasan tertentu yang akan dikuatkan dengan ayat-ayat lainnya. Kedua, dalam konteks pembahasan topik yang sama dalam Al-Qur'an. Tahap ini berarti mengembangkan ayat secara pararel, dengan kata lain keterkaitan atau munasabah antar ayat-ayat yang satu tema pembahasan. Dalam hal ini, dapat disamakan dengan metode

31 Amina Wadud, Qur'an and Woman..., 5 . 
maudui' yang akhirnya ditemukan idea utama dalam tema tersebut. Ketiga, menganalisa bahasa yang sama dan struktur sintaksis yang digunakan di seluruh bagian AlQur'an. Setelah menemukan ayatayat yang berkaitan atau satu tema, maka ayat-ayat tersebut harus dianalisis secara bahasa, sehingga dapat ditemukan perbedaan atau persamaan terkait dengan terma yang merujuk pada perempuan atau lakilaki. Keempat, bersikap benar-benar berpegang teguh pada prinsipprinsip Al-Qur'an. Hasil dari anlisis bahas tersebut, baik itu berupa perbedaan atau persamaan antara laki-laki dan perempuan, harus tunduk pada prinsip utama AlQur'an, seperti keadilan, kesamaan dan sebaginya. Terakhir menurut konteks Weltanschauung Al-Qur'an atau pandangan dunianya. Hasil penafsiran harus disesuaikan dengan world-view Al-Qur'an. Sehingga dapat relevan dengan konteks kekinian.

E. Nusyuz Sebagai Disruption of Marital Harmony
Banyak tema-tema yang ditafsirkan ulang oleh Wadud terkait dengan isu-isu perempuan, salah satunya tentang nusyuz. Dalam AlQur'an ayat membicarkan nusyuz merujuk pada Q.S al-Nisa (04): 34, yakni;

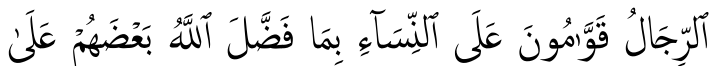

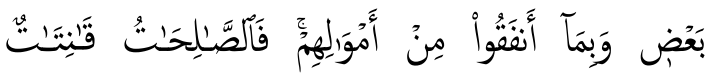

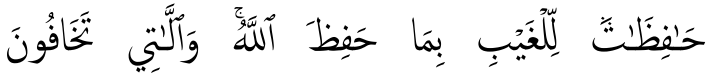

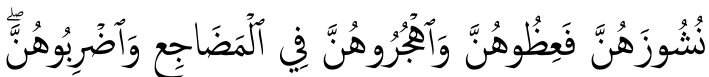

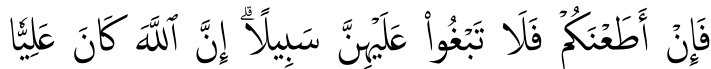
كَير

Artinya:

Laki-laki (suami) itu pelindung bagi perempuan (istri), karena Allah telah melebihkan sebagian mereka (laki-laki) atas sebagian yang lain (perempuan), dan karena mereka (laki-laki) telah memberikan nafkah dari hartanya. Maka perempuan-perempuan yang saleh adalah mereka yang taat (kepada Allah) dan menjaga diri ketika (suaminya) tidak ada, karena Allah telah menjaga (mereka). Perempuan-perempuan yang kamu khawatirkan akan nusyuz, hendaklah kamu beri nasihat kepada mereka, tinggalkanlah mereka di tempat tidur (pisah ranjang), dan (kalau perlu) pukullah mereka. Tetapi jika mereka menaatimu, maka janganlah kamu mencari-cari alasan untuk menyusahkannya. Sungguh, Allah Mahatinggi, Mahabesar. 
Terkait dengan adanya ayat nusyuz, ada beberapa point penting menurut Wadud yang menjadi pijakan awal dalam penafsirannya; Pertama, lafad qānitāt. Dalam ayat ini, lafad tersebut menggambarkan wanita-wanita yang "baik", namun selalu diterjemahkan manjadi "ta' at" dan akhirnya diasumsikan bermakna "taat kepada suami". Secara keseluruhan dalam konteks AlQur'an, lafad qānitāt dalam berbagai bentuk derivasinya berjumlah $13 .{ }^{32}$ Merujuk pada laki-laki menurut Wadud ada tiga tempat, sedangkan merujuk pada perempuan ada empat tempat. ${ }^{33}$ Lebih jauh, Wadud membedakan lafad qānitāt dengan lafad ta'at. Lafad qānitāt mengambarkan suatu karakteristik atau ciri personalitas kaum yang beriman kepada Allah. Mereka cenderung bersikap kooperatif satu sama lain dan tunduk dihadapan

$32 \mathrm{Fu}^{\prime}$ ad Abdu al-Baqi, al-Mu'jam alMufahras li Alfad al-Quran al-Karim, (Beirut: Dar al-Fikr, 1992), 553.

33 Lafad qanitāt merujuk pada laki-laki; Q.S. 2:238, 3:17, 33:35 sedangkan yang merujuk pada perempuan: Q.S. 4:34, 33:34, 66:5, 66:12.
Allah. Berbeda dengan lafad kedua, yakni berupa ketaatan di antara makhluk ciptaan atau pada Allah. ${ }^{34}$ Pernyataan di atas mencerminkan analisis paradigmatik dalam menelusuri kata qānitāt, yang akhirnya membedakannya dengan lafad tha'at. Lafad qānitāt berjumlah 13 dalam Al-Qur'an yang secara khusus berkaitan dengan keta'atan pada Allah. Selain itu, lafad ini juga digunakan mahluk hidup secara umum, tidak hannya manusia, seperti pada Q.S. al-Baqarah (02): 116 dan Q.S. al-Rum (30): 26 yang berupa kepatuhan langit dan bumi. Dengan kata lain, tidak ada pengunaan lafad tersebut merujuk pada keta'atan sesama mahluk hidup. Namun satu ayat yang lepas dari jangkauan Wadud terkait hipotesisnya, dalam surat Q.S. Al-Ahzab (33):31 dengan

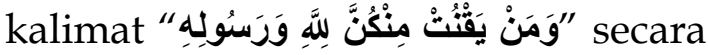
tidak langsung mematahkan pedapat Wadud bahwa lafad qānitāt digunakan ekskluif dalam keta'atan pada Allah. Menurut al-Wahidi lafad

34 Amina Wadud, Qur'an and Woman..., 74. 
qānitāt itu berarti ta'at yang bersifat umum, bisa ta'at pada Allah dan pada suami. ${ }^{35}$ Selain itu, dalam ayat sesudah dan sebelum ayat tersebut, konteks bembicaraan adalah tentang peringatan terhadap seorang istri Nabi yang melakukan perbuatan keji dan kepatuhan istri-istri Nabi terhadap Allah dan Nabi. ${ }^{36}$ Sehingga konteks pembicaraan dalam ayat ini dengan ayat al-Nisa (04): 34 tidak jauh berbeda, terkait dengan patuh atau tidak patuh seorang istri pada suami dan juga berupa keta'atan pada Allah.

Mungkin dalam surat Q.S. AlAhzab (33): 31, menjadi pengecualian bagi Wadud, walau ia tidak menjelaskannya. Akan tetapi bila kata qānitāt dalam Q.S al-Nisa (04): 34 dipahami sebagai keta'atan pada Allah ansich, maka bagaimana pemahaman struktur kalimat setelahnya. Dengan kata lain bagaimana pemahaman secara utuh ayat tersebut atau analisis

35 Al-Razi, Mafātị̣ al-Ghaib (Beirut: Dar Ihya al-Turas al-'Arabi, 2000), juz x, 70.

36 Al-Zamakhsyari, Al-Kasyāf (Beirut: Dar al-Kitab al-'Arabi, 2001) juz iii, 536. sintagmatiknya. Hal ini, menjadi kekurangan Wadud dalam menafsirkan ayat nusyuz, ia hanya mengambil lafad qānitāt tanpa menganalisis secara keseluruhan struktur bahasa ayat tersebut. Dalam

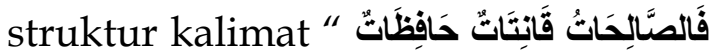
"dapat dikatakan kalam yang sempurna. Kalimat tersebut merupakan kalam insyai (mubtada' dan khabar), yakni sebuah pemberitaan bahwa wanita yang shalihah adalah wanita yang ta'at

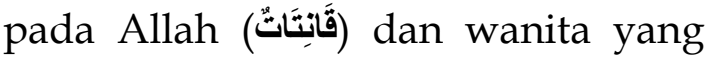
menjaga haq suami (حَافِظًَاتُ (حَ). Sedangkan lafad (للْنَفَبْب) berarti dalam keadaan tidak kelihatan, yakni dapat dipahami sesatu yang dijaga itu tidak terlihat atau ketika suami tidak ada. ${ }^{37}$ Dengan demikian, wanita yang shalihah adalah wanita yang ta'at pada Allah dan juga ta'at pada suaminya, al-ta'rif dalam lafad ） berfaidah istighraq (keseluruhan), sehingga wanita secara keseluruhan adalah sahlihah

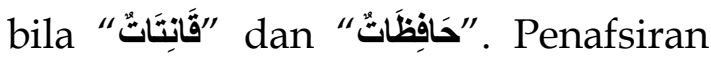

37 Abu Hayyan, Al-Bahr Al-Muhit (Bairut: Dar al-Fikr, 2000), juz iii, hlm. 624. Al-Zamakhsyari, Al-Kasyäf, juz i, 506. 
lain mengatakan bahwa aspek keta'atan istri bila hadirnya suami

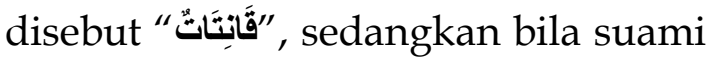
tidak ada disebut " 38 Berdasrakan analisis sintagmatik, lafad qānitāt tidak bisa dipahami hanya dengan melihat lafad itu sendiri, melainkan harus melihat struktur kalimat secara keseluruhan. Qānitāt merupakan sifat wanita yang shalihah, yang dengannya ia akan ta'at dan patuh pada Allah dan suaminya. Hal ini diperkuat dengan Q.S. al-Ahzab (33) :31, dalam ayat tersebut juga disebutkan bahwa wanita yang beramal shalih dan qanitaat akan mendapatkan pahala.

Kedua, setelah menetapkan makna kata qānitāt. Kata menjadi

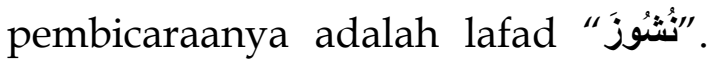
Dalam Al-Qur'an kata "nusyuz" juga digunkan untuk laki-laki, yakni Q.S. 4:124 dan pada perempauan. Ketika merujuk pada perempuan kata nusyuz diartikan ketidakpatuhan isteri kepada suami. Sedangkan ketika merujuk pada suami berarti sikap tidak sewenang-wenagan

38 Al-Razi, Mafätị̣ al-Ghaib, juz x, 70. suami karena tidak mau memberikan haknya. ${ }^{39}$ Berdasarkan digunakannya kata tersebut untuk laki-laki dan perempuan, menurut Wadud nusyuz tidak dapat diartikan ketidakpatuhan pada suami (disobidience to the husban) tetapi mempunyai pengertian adanya gangguan keharmonisan dalam rumah tangga "disruption of marital harmony". ${ }^{40}$

Sama dengan sebelumnya, dalam tahap ini, kata nusyuz menjadi pioner dalam menentukan tema sebenanya tentang nusyuz. Namun dalam menentukan makna tentang nusyuz menurut Wadud, terlihat simple. Yakni berdasarkan adanya penggunaan nusyuz bagi laki-laki dan perempuan dalam sebuah kehidupan rumah tangga, maka dipahami tidak keharmonisan dalam rumah tangga. Sampai di sini, tidak ada analisis yang digunakan Wadud, baik itu paradigmatik atau sintagmatiknya. Nusyuz secara bahasa adalahalirtifa' atau tempat yang tinggi atau

${ }^{39}$ Al-Zamakhsyari, Al-Kasyaf, juz i, 506. Al-Razi, Mafatih al-Ghaib, juz x, 71.

40 Amina Wadud, Qur'an and Woman, 75. 
menonjol dalam permukaan bumi,,41 berarti orang yang nusyuz adalah orang yang meninggikan diri atau sombong dengan melakukan pelanggaran. ${ }^{42}$ Dalam Al-Qur'an hanya ada lima kata nusyuz,43 dua diantaranya terkait dengan tindakan tidak menyenangkan suami atau istri. Berangkat dari definisi bahasa, pemahaman bahwa nusyuz, sebagai ketidak harmonisan terlalu juah. Selain itu, ketidak harmonisan tidak hanya disebabkan oleh prilaku suami atau istri akan tetapi dari pihak lain dapat menyebabkan ketidak harmonisan. Dengan begitu, sudah jelas antara nusyuz berbeda dengan ketidak harmonisan, namun nusyuz dapat menyebabkan ketidak harmonisan.

وَاللَّاتِي " Dalam struktur kalimat "تَخَافُونَ نُشُُوزَهُنَّ , hal yang lepas dari pengamatan Wadud adalah kata "وَالَلَّتِي , ia tidak menyebutkan isim mausul tersebut merujuk pada lafad

41 Ibn Manzur, Lisan al-'Arabi (Mesir: Dār al-Mishriyyah, 1992), 4425.

42 Sayyid Qutb, Fi Dhilal al-Qur'an (Bairut: Dar al-Suruq, 2003), juz ii, 653.

43 Fu'ad Abdu al-Baqi, al-Mu'jam alMufahras li Alfad al-Quran al-Karim, 701. apa. Bila huruf wawu merupakan isti'nafiyah, maka kata "وَاللَّانتي" tidaklah merujuk pada lafad “ فَالصَّالِحَاتُ "قََانْتَاتُ لحَافِظَاتُ

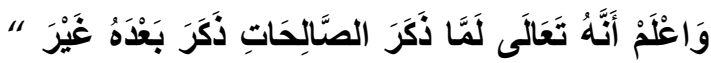

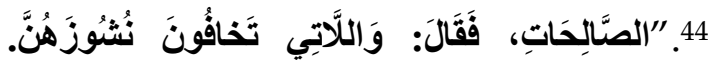
Dengan demikian, wanita yang melakukan nusyuz, bukanlah wanita yang shalihah. Dengan kata lain, hal yang memebedakan antara shalih dan tidak shalih antar lain adalah prilaku nusyuz.

Terhadap tindakan isteri yang nusyuz, Wadud mengatakan bahwa Al-Qur'an memberikan tiga tahap solusi: pertama; solusi verbal, baik antara suami isteri sendiri sebagaimana dalam ayat Q.S. an-Nisa (04): 34 atau melibatkan orang lain sebagai penengah (sebagaimana dalam surat al-Nisa ayat 35 dan 128). Kedua; boleh dipisahkan (tempat tidur), tetapi hanya dalam kasuskasus eksterim saja langkah terakhir boleh diterapkan. ketiga, memukul mereka diperbolehkan. ${ }^{45}$

\footnotetext{
${ }^{44}$ Al-Razi, Mafatih al-Ghaib, juz x, 71.

45 Amina Wadud, Qur'an and Woman,
} 75. 
Tahapan yang diterapkan Wadud tidak jauh berbeda dengan bebrapa ulama, walapun terdapat pendapat yang memahami bahwa hukuman tersebut tidak bersifat bertahap. ${ }^{46}$ Perbedaanya yang mencolok terletak pada dikirimnya perwakilan atau hakim (al-Nisa ayat 35 dan 128), menurut Wadud termasuk tahap yang kedua. Sedangkan pendapat beberapa ulama, itu merupakan tahap paling akhir jika pertikaian masih berlangsung atau keadaan sangat menghawatirkan. ${ }^{47}$ Menurut Sayyiq Qutb, tiga tindakan yang sebelumnya dilakukan apabila nusyuz belum gawat dan dapat ditanggulangi. Apabila keadaan sudah darurat, maka tiga tindakan tersebut tidak dilakukan. Sehingga menggundang juru damai harus dilakukan apabila ada kehawatiran terjadinya persengketaan. ${ }^{48}$

${ }^{46}$ Al-Razi, Mafatih al-Ghaib, juz x, 72.

${ }^{47}$ Ali al-Shabuni, Rawaih al-Bayan Tafsir Ayat al-Ahkam (Damaskus: Maktah alGhazali, 1980) juz i, 469-472.

${ }^{48}$ Sayyid Qutb, Fi Dhilal al-Qur'an, 656.
Ketiga, kata yang perlu dijelaskan lebih jauh adalah kata daraba (memukul) sebagai salah satu langkah dari ketiga langkah dalam menyelesaikan persoalan nusyuz. Kata daraba menurut Wadud tidak mesti menyatakan kekuatan atau kekerasan. Kata ini digunakan dalam Al-Qur'an, misalnya dalam ungkapan "daraba Allah matsala" (Allah memberikan atau menetapkan sebagai contoh). Menurutnya, berdasarkan realitas dan data yang ada kekerasan yang berlebihan terhadap wanita yang ditujukan dalam biografi para sahabat dan oleh kebiasaan yang dikecam dalam AlQur'an (seperti pembunuhan bayi perempuan), maka ayat ini harus diartikan sebagai larangan tindak kekerasan tanpa kendali terhadap wanita. Jadi, bukan izin melainkan larangan keras terhadap kebiasaan yang ada. ${ }^{49}$

Pemahaman Wadud tidak memungkiri bahwa kata ḍaraba dalam ayat ini diartikan sebagai

49 Amina Wadud, Qur'an and Woman, 76. 
memukul. Pendapat ulama tentang kata tersebut juga diartikan memukul, namun ada ulama yang mengahruskan ketika memukul tidak dilakukan secara keras, tidak mencederai dan tidak pada sembarang tubuh. Pendapat lain mengutamakan tidak memukul, jika memukul itu berhukum mubah. 50 Persoalan yang menjadi konsen Wadud adalah adanya pemukulan atau kekerasan dalam rumah tangga, berdasarkan pemahaman yang salah pada Q.S al-Nisa (04): 34. Padahal dalam ayat tersebut, memukul isteri merupkan cara paling akhir, bukan hal yang seenaknya harus dilakukan. 51

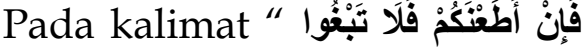

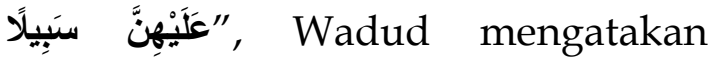
bahwa kata tha'at dalam ayat ini perlu direnungkan secara kontekstual. Menurutnya keta'atan ini adalah hukuman bersyarat, bukan suatu perintah. Dengan demikian, menurut Wadud Al-Qur'an tidak

50 Al-Zamakhsyari, Al-Kasyaf, juz i, 507. Al-Razi, Mafatih al-Ghaib, juz x, 72.

51 Amina Wadud, Qur'an and Woman, 76. pernah memerintahkan seorang wanita supaya mentaati suaminya, Al-Qur'an juga tidak pernah menyatakan bahwa ketaatan kepada sumi merupakan ciri-ciri wanita yang baik Q.S. at-Tahrim (66): 5. Juga bukan persyaratan bagi wanita untuk memasuki komunitas Islam Q.S. alMumtahanah (60): 12. Lebih jauh model hubungan yang dikehendaki Wadud bukan berdasarkan pada modal ketundukan dan ketaatan buta, tetapi berdasarkan pada pola hubungan bahwa laki-laki merupakan patner untuk saling memperbaiki emosi, intelektual, ekonomi dan spiritual. kepercayaan terhadap keharusan mematuhi suami ini adalah peninggalan model perkawinan dari perkawinan bentuk penundukan (budak). ${ }^{52}$

Penafsiran yang dikatakan Wadud bahwa keta'atan ini adalah hukuman bersyarat, bukan suatu perintah itu dapat dibenarkan bila hanya mengaju pada struktur kalimat tersebut. Lafad “ merupakan syarat dan jawab

52 Amina Wadud, Qur'an and Woman, 77-78. 
syaratnya adalah "فَ', sehingga dapat dipahami "bila mereka ta'at kepadamu, maka kamu jangan mencari cara untuk menyusahkan". Hal ini tidak akan terjadi bila dipahai dari awal, yakni “wanita yang kamu khawatirkan nusyuznya, maka nasehatilah, pisahlah mereka di tempat tidur, dan pukullah mereka, jika mereka ta'at kepadamu dengan tidak melakukan nusyuz, maka janganlah kamu menyusahkannya".

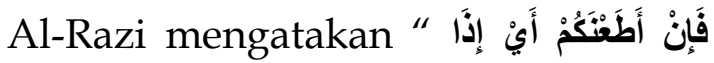

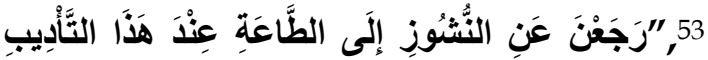
pernyataan di samping menunjukan “jika meraka menta'ati kamu, yakni berubah dari membangkang (nusyuz) menjadi ta'at". Tidak jauh berbeda dengan pendapat Abu Hayyan yang

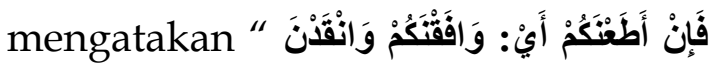
54 yakni wanita yang nusyuz mau menerima dan menyetujui apa yang diwajibkan Allah kepadanya untuk patuh pada suami. Selain itu, bila dari penggalan ayat tersebut menyimpulkan bahwa Al-Qur'an tidak memerintahkan

\footnotetext{
${ }^{53}$ Al-Razi, Mafatih al-Ghaib, juz x, 73.

${ }^{54}$ Abu Hayyan, Al-Bahr Al-Muhit, juz
} iii, 628 . wanita untuk ta'at pada suami, mungkin terlalu menggeneralisasi. Dalam surat Q.S. 33:31, dapat mewakili bahwa seoarang istri harus ta'at pada suami dengan menganalogikan keharusan istri-istri nabi ta' at pada nabi.

\section{SIMPULAN}

Amina Wadud merupakan salah satu tokoh wanita yang berusaha untuk membongkar pemikiran dan penafsiran yang bias patriarkhi melalui rekonstruksi metodologi tafsirnya. Paradigma penafsiran yang ia gunakan adalah hermeneutika tauhid, dengan metode holistik. Secara geneologi, Wadud terpengaruh pemikiran Gadamer, karena mengamini tidak ada penafsiran yang benar-benar objektif. Dalam praktek penafsirannya, setidaknya ada lima level analisis yang ia gunakan yang merupakan pengembangan dari tafsir Al-Qur'an bi Al-Qur'an.

Wadud memahami nusyuz, sebagai bentuk ketidak harmonisan rumah tangga. Berbeda dengan 
pendapat umum yang mengatakan nusyuz adalah bentuk ketidak patuhan suami atau istri. Dalam hal hubungan pernikahan, Wadud berpendapat Al-Qur'an tidak pernah memerintahkan seorang wanita supaya mentaati suaminya, tetapi berdasarkan pada pola hubungan bahwa laki-laki merupakan patner untuk saling memperbaiki dan melengkapi. Akan tetapi, sebagaimana Wadud katakan, bahwa lafad qānitāt hanya berlaku pada ketaatan manusia kepada Allah, terbantahkan dengan adanya Q.S. AlAhzab (33): 31. Dalam ayat tersebut kata qānitāt digunakan pula untuk keta'atan sesama mahluk hidup. Selain itu, karena penggunaan kata nusyuz bagi laki-laki dan perempuan dalam sebuah kehidupan rumah tangga, kemudian secara sederhana dipahami tidak keharmonisan dalam rumah tangga. Padahal ketidak harmonisan tidak hanya disebabkan oleh prilaku suami atau istri, akan tetapi dari pihak lain dapat menyebabkan ketidak harmonisan. 


\section{DAFTAR PUSTAKA}

Abdul, Fu'ad, al-Baqi. al-Mu'jam alMufahras li Alfad al-Quran alKarim, Beirut: Dar al-Fikr, 1992

Abou, Khaled, el-Fadl. Speking in God's Name Islamic Law, Authority and Women. England: Oneworld Oxfor, 2003

Al-Razi, Mafātih al-Ghaib. Bairut: Dar Ihya al-Turas al-'Arabi, 2000

Al-Zamakhsyari, Al-Kasyaf. Bairut: Dar al-Kitab al-'Arabi, 2001

Baidawi, Ahmad. Tafsìr Feminis; Kajian Perempuan dalam alQur'ān dan Para Mufassir Kontemporer. Bandung: Nuansa, 2005

Barlas, Asma. Suha Taji-Farouki, ed. Modern Muslim Intellectuals and the Qur'an. London: Oxford Univercity Press, 2005

Bleicher, Josep. Contemporery Hermeneutis: Hermeneutis as Method, Philosofhy and Critique. London: Raoutlege \& Kegan Paul, 1980

Georg, Hans, Gadamer. Truth and Method. New York: Seabury Press, 2004
Hayyan, Abu. Al-Bahr Al-Muhiț. Bairut: Dar al-Fikr, 2000

Jannah, Miftahul. 'Nizāàm Al-Qur'ān', MAGHZA: Jurnal Ilmu Al-Qur'an Dan Tafsir, 3.1 (2018), 79-92 https://doi.org/10.24090/magh za.v3i1.1957

Kurzman, Charles. Liberal Islam: A Source Book. New York: Oxford University Press, 1998

Manzur, Ibn. Lisān al-'Arabi. Mesir: Dār al-Mis\}riyyah, 1992.

Mustaqim, Abdul. Pergeseran Epistemologi Tafsir. Yogyakarta: Putaka Pelajar, 2008

Nasution, Khoiruddin. Fazlur Rahman tentang Wanita. Yogyakarta: Tazzafa dan Accademika, 2002

Rahman, Fazlur. Islam and Modernity. Chicago: University Press, 1982

Saeed, Abdullah. Islamic Thought: An Introduction. London and New York: Routledge, 2006

Syamsuddin, Sahiron. Hermeneutika dan Pengembangan Ulum AlQur'an. Yogyakarta: Nawesea Press, 2009

Suryocondro, Sukanti. “Timbulnya Perkembangan Gerakan Wanita 
Indonesia" dalam Kajian Wanita

dalam Pembangunan. Jakarta:

Yayasan Obor Indonesia, 1995

Wadud, Amina. Inside the Gender Jihad: Women's Reform in Islam. Oxford: Oneworld, 2006

Qur'an and Woman:

Rereading the Sacred Text from a

Woman's Perspective. New York:

Oxford University Press, 1999 